\section{P-109 系統的前立腺生検法についての検討-大き} か?

\author{
會敷中央病院泌尿器科1) 京都大学 ${ }^{2)}$ \\ 寺田 直樹1) 松田 陽介 ${ }^{1}$ 前川信也1) 大久保和俊1) \\ 小倉 啓司 ${ }^{1)}$ 荒井陽一1) 前田浩2)
}

【目的】系統的前立腺生検に扔いて、特に大きな前立腺に対し生 検本数を増やすことの意義についての検討。【対象と方法】 PSA上 昇(IMx 4.0ng/ml以上)を認めた患者434人に対し下記のプロトコール にて前立腺生検を行った。A群：前立腺体積に関わらず系統的6力 所生検(1996 '97 168例)。B群：前立腺体積に応じ50ml以下は6力所、 50mi以上は12力所生検(1998～'99 266例)。それらの各群における診 断率の違いを検討した。【結果】癌陽性率は、全体では、A群で 168例中61例(36.3\%)、B群で266例中94例 $(35.3 \%)$ 。前立腺体積 $50 \mathrm{ml}$ 以上の患者に拀いては、A群で57例中16例(28.1\%)、B群で72例中17 例 $(23.6 \%)$ と、いずれも統計学的有為差は認めなかった。前立腺体 積 $50 \mathrm{ml}$ 以上、 $4.0<\mathrm{PSA}<20.0 \mathrm{ng} / \mathrm{ml}$ の患者においては、A群で39例 中3例(7.7\%)、B群で62例中10例(16.1\%)であり、B群にて診断率の 上昇を認めた。その12力所生検10例のうち、追加した内側6r所の みより癌陽性であったものは2例(20.0\%)であった。結論】PSA值 が境界領域の大きな前立腺に対して、生検本数を増やすことによ って、診断率が问上する可能性が示唆された。

前立腺痁 系統的前立腺生検 生検本数

\section{P-111 前立腺癌および肥大症の発症とCYP17遺伝 子多型の関連}

\author{
秋田大学 泌尿器科1) 京都大学 泌尿器科2) \\ 張力青1) 羽渕友則 ${ }^{1 ｝ \text { 佐々木 隆聖1）鈴木丈博1）下田 直威1） }$ \\ 佐藤 一成 ${ }^{1)}$ 佐藤 滋 ${ }^{1)}$ 小川修2) 加藤 哲郎 ${ }^{1)}$ \\ 【目的】CYP17遺伝子はcytochrome P450c17-alphaをコードする。こ \\ の酵素にはsteroid hormone合成に重要な17-alpha-hydroxylase、17,20- \\ lase活性がある。最近CYP17遺伝子の5'領域に 1 塩基置換の多型が \\ あり、この多型により転写活性に重要な役割を果たすCCACC box \\ （Sp-1 site）が形成されることがわかってきた。またこの多型と乳 \\ 癌との関連が報告されている。我々は前立腺癌（PCa）および前 \\ 立腺肥大症（BPH）の発症とCYP17遺伝子多型との関連を調べた。 \\ 【対象と方法】対象はPCa患者252名、BPH患者202名、女性対照193 \\ 名、男性対照131名である。対象者の白血球DNAを基に制限醅素 \\ MspA1を用いたPCR-RFLP法によりCYP17の多型解析を行った。 \\ 【結果】CYP17遗伝子のgenotypeはPCa vs 男性対照群、PCa vs 女性 \\ 群、BPH vs 男性対照群で有意な違いが有った。 A 1/A1 genotypeの男 \\ 性は他のgenotype (A1/A2 + A2/A2) の男性に比べて、PCaならびに \\ $\mathrm{BPH}$ のリスクが、それぞれ1.8倍、1.7倍となり、転移性PCaのリス \\ クは2.1倍に増加するとの結果を得た（いずれも $\mathrm{p}<0.05 ）$ 【考察】 \\ CYP17遺伝子多型はPCaやBPHの発症に関与すると考えられた。 \\ $\mathrm{PCa}$ のリスクアレルは報告されている乳癌のリスクアレルとは逆 \\ であると考えられた。今後、PCaの病期、異型度、また年龄、木 \\ ルモンなどの背景因子も考慮し、解析していく予定である。 \\ 前立腺癌 遗伝子多型 CYP17
}

\section{P-110 前立腺生検症例に対する各パラメーターの 有用性と再生検症例に関する検討}

\begin{abstract}
岩手県立中央病院 泌尿器科1) 岩手県立大船渡病院 泌尿 器科2) 岩手県立北上病院 泌尿器科 3 )

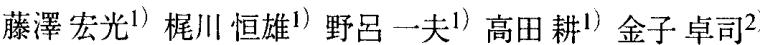
玉田博志 3 )

【目的】当科で施行した前立腺生検症例に対し，各パラメーター の有用性と初回陰性の再生検癌症例に関し検討した.【方法】1997 年4月から 1999年6月まで, PSA，DRE，TRUSの何れかに異常を認 めた309例(47〜90歳, 平均69.7歳)に対し経直腸的前立腺生検を累 計354回施行した．初回は系統的6ヶ所生検を，再検例は6ヶ所生検 に加えtransition zone(TZ)両葉各 2 ヶ所の生検を追加した．統計学的 検討は303症例，347例の生検に対し行った.【結果】102例(33.7\%) に癌を検出，陰性症例と癌症例の間にPSA, PSAD, PSATZD, free/total(F/T)で有意差を認めた $(\mathrm{p}<0.05)$. PSA $4.0 \sim 10.0 \mathrm{ng} / \mathrm{ml}$ のgray zoneではPSAD，PSATZDに有意差(p<0.05)を認めたが，F/Tで有意 差を認めなかった，再検症例44例中8例(18.2\%)に癌を検出したが， PSA, PSAD, PSATZD, PSA velocityに有意差を認めなかった。初 回検出癌症例と再検癌症例ではPSATZDに有意差 $(\mathrm{p}<0.05)$ を認め た. 陰性症例と再検癌症例の初回生検の比較ではPSAD, PSATZD に有意差 $(\mathrm{p}<0.05)$ を認めた．初回検出癌症例と再検癌症例に分化 度，コア陽性数に有意差を認めず，TZのコアに単独で癌を認めた 症例はなかった【【考察】再生検を考慮した場合, PSAだけでなく， PSAD，PSATZDでのfollow upも有効と考えられた，TZの生検は今 後摘出標本と比較し検討を要すると考えられた。

prostate cancer PSA rebiopsy
\end{abstract}

\section{P-112 前立腺癌におけるCox-2mRNAの発現及び COX-2阻害薬によるApoptosisの誘遵}

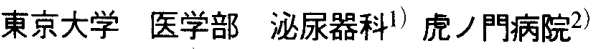 \\ 都立府中病院 ${ }^{3}$
}

上條利幸 ${ }^{1 ｝ \text { 佐藤 俊和 }{ }^{2)} \text { 永冨 } \text { 裕 }^{3)} \text { 北村 唯一1) }$

目的：前立腺癌組織では、プロスタグランジン $(\mathrm{PG})$ 濃度が高く 癌増殖との関連が指摘されている。シクロオキシゲナーゼ $(\mathrm{COX})$ はPG合成酵素であり、種々の癌発生進展に寄与していることが報 告されている。今回我々は、前立腺癌における 現と前立腺癌細胞株に対するCOX-2阻害薬の効果を検討した。方 法：1）手術にて摘出した前立腺癌及び正常前立腺（膀胱全摘標 本）を用いてRNAを抽出し半定量的RT-PCR法にてmRNA発現量 を比較検討した。2）前立腺細胞株LNCaP,PC-3を用いてCOX-2阻 害薬Etodolac,NS398を投与し各濃度及び各投与時間における細胞增 殖抑制効果をMTTassayにて評価した。またその機序の解明として DNA fragmentation assay を施行した。結果: 1) 前立腺癌では、正 常組織と比較してCOX-2mRNAが過剩に発現していた。2) Etodolac,NS398投与にてLNCaP、PC-3ともに容量及び時閒依存的に 細胞数が減少した。この時にApoptosisが誘導されていた。考察： COX-2の過㮃発現はPG過剩合成による前立腺癌の増殖に関与する ことが示唆された。COX-2阻害薬は前立腺㾔の細胞死を起こし、 その機能の一因はApoptosisの誘導であった。現在nude mouse を用 いたin vivo modelの系でも検討中である。結論：前立腺癌の治療薬 としてCOX-2阻害薬の可能性が示唆された。 前立腺癌 COX-2 Apoptosis 